\title{
The training and praxis of the nurse in the light of nursing theories
}

\author{
Formação e práxis do enfermeiro à luz das teorias de enfermagem \\ La formación y la praxis del enfermero bajo las teorías de enfermería
}

Bruna Pegorer Santos'
ORCID: 0000-0003-3986-7157
Flávia Mendes de Sá'
ORCID: 0000-0001-5899-902X
Jessica Eugenio Pessan'
ORCID: 0000-0001-6614-8399

Laudicéia Rodrigues Criveralo" ORCID: 0000-0001-7077-5678

Lívia Nogueira Bergamo'

ORCID: 0000-0002-5206-6832

Viviane Cristina de Albuquerque Gimenez' ORCID: 0000-0002-0095-2840

Cassiana Mendes Bertoncello Fontes' ORCID: 0000-0002-6579-8637

Gabriel Mendes Plantier' ORCID: 0000-0002-2886-7760

'Universidade Estadual Paulista Júlio de Mesquita Filho. Botucatu-SP, Brasil.

"Instituto Lauro de Souza Lima, Enfermagem. Bauru-SP, Brasil.

How to cite this article: Santos BP, Sá FM, Pessan JE, Criveralo LR, Bergamo LN, Gimenez VCA, et al. The training and praxis of the nurse in the light of nursing theories. Rev Bras Enferm. 2019;72(2):566-70. doi: http://dx.doi.org/10.1590/0034-7167-2018-0394

\section{Corresponding Author: \\ Gabriel Mendes Plantier \\ E-mail: gabrielplantier@hotmail.com}

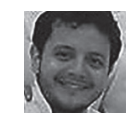

Submission: 06-08-2018

Approval: 09-09-2018

\section{ABSTRACT}

Objective: to report the experience of the development of nursing knowledge from nursing theories and points of contact with the nurse's praxis. Method: case report on the reflections on contents addressed in the discipline offered in the Graduate Program in Nursing in a federal public university. The students presented seminars approaching the main nursing theories, generating extensive discussion and correlating them with the nurse's practice. Review and reflection on the contents addressed. Result: two themes were defined: the training of nursing undergraduate students and the development of knowledge in relation to the concepts of nursing theories; and care models and nurses' critical reasoning about the applicability of nursing theories. Final Consideration: the reflections produced permeated the development and acquisition of knowledge and of representative meanings of healthcare practice from the assumptions and constructs of the theories.

Descriptors: Nursing theory; Education in Nursing; Postgraduate Education in Nursing; Nursing Students; Nursing Process

\section{RESUMO}

Objetivo: relatar a experiência da construção do conhecimento de enfermagem a partir das teorias de enfermagem e dos pontos de tangência com a práxis do enfermeiro. Método: relato de experiência sobre as reflexões a partir de conteúdos abordados na disciplina oferecida em Programa de Pós-Graduação de Enfermagem stricto sensu de uma universidade pública estadual. Foram apresentados seminários pelos alunos trazendo as principais teorias de enfermagem, gerando ampla discussão correlacionando-as à prática do enfermeiro. Revisão e reflexão dos conteúdos abordados. Resultado: definiramse dois temas: a formação do aluno de graduação de enfermagem e a construção do conhecimento em relação aos conceitos das teorias de enfermagem; e modelos assistenciais e o raciocínio crítico do enfermeiro acerca da aplicabilidade das teorias de enfermagem. Considerações Finais: as reflexões produzidas permearam a construção e apreensão do conhecimento e dos significados representativos da prática assistencial a partir dos pressupostos e constructos das teorias.

Descritores: Teoria de Enfermagem; Educação em Enfermagem; Educação de PósGraduação em Enfermagem; Estudantes de Enfermagem; Processo de Enfermagem.

\section{RESUMEN}

Objetivo: exponer la experiencia de construcción del conocimiento en enfermería desde las teorías de enfermería y los puntos de tangencia con la praxis del enfermero. Método: reporte de experiencia con reflexiones de los contenidos abordados en la disciplina ofertada en el Programa de Posgrado stricto sensu en Enfermería de una universidad pública estatal. Los estudiantes presentaron seminarios en que se plantearon las principales teorías de enfermería, generando una amplia discusión, correlacionándolas con la práctica del enfermero. Revisión y reflexión de los contenidos planteados. Resultado: se definieron dos temas: la formación del estudiante de grado de enfermería y construcción del conocimiento con relación a los conceptos teóricos del área; y los modelos asistenciales y el raciocinio crítico del enfermero acerca de la práctica de las teorías de enfermería. Consideraciones Finales: las reflexiones posibilitaron la construcción y aprehensión del conocimiento, así como los significados representativos de la práctica asistencial desde las premisas y las concepciones teóricas. Descriptores: Teoría de Enfermería; Educación en Enfermería; Educación de Posgrado en Enfermería; Estudiantes de Enfermería; Proceso de Enfermería. 


\section{INTRODUCTION}

This case report focuses on the development of teaching activities performed during the classes on the elective discipline called "nursing theories: from knowledge development to taxonomies NANDA, NIC and NOC". The course is offered in the Nursing Graduate Programs of academic master's and doctorate and of professional master's of the Department of Nursing of the School of Medicine of the São Paulo State University "Júlio de Mesquita Filho" at Botucatu. The six master students and the two doctoral students are regularly enrolled in the discipline.

The discussions emerging from the seminars converged in aspects of the training of the graduate student and of nurses in the contexts of practice, teaching, care and research, so that the prospect of the reflections correlated with the applicability in the work process.

At the end of the course, the actors involved - students and teachers - evaluated how significant the study of issues related to the valorization of concepts from the theories was for the learning process and how they are still poorly used in nurses' training. Thus, the experience is described considering the potential of significance for the nursing field and the theoretical basis for the development of critical thinking in the decision-making process.

\section{PROGRAM CHARACTERIZATION}

The development of the activities of the discipline in question becomes the use of the body of knowledge of nursing theories important, as well as their rich concepts through the way these different "looks" understand and can explain the phenomena of the practice of nurses and nursing.

Thus, as the seminars were presented, questions and reflections on how the process of nursing knowledge development through the concepts of the theories analyzed is emerged. In addition, the points of contact of the theories with the nurses' praxis were discussed. The problem was found: divergence between the assumptions of the nursing theories and the current praxis in the field.

Therefore, for a free and impartial reflection on the problem, students need to analyze their practices and modus operandi. They exploited other viewpoints, objectively focused on concepts addressed from the theories studied that relate to the nurse's praxis.

\section{DESCRIPTION OF THE EXPERIENCE}

The total of 12 weekly face-to-face classes with eight students occurred. The specific objectives of the discipline were: to identify the assumptions of some nursing theories and correlate these assumptions with the praxis of nurses; to reflect about the insertion of nursing theories in the practice of nurses and to characterize it; to analyze and use the concepts of the theories in the nursing process; to use classifications of standardized terms in the diagnoses, interventions and outcomes of nursing.

The schedule of the discipline encompassed: the approach of some nursing theories and their relationship with nursing praxis in the context of teaching, research and care; the construction process of the body of knowledge of the nursing science; and reflections on the use of conceptual assumptions of nursing theories and taxonomies, which contribute to the maintenance of the autonomy of nurses and of the nursing process.

The theoretical constructs of the theories by Dorothea Orem, Ida Jean Orlando, Wanda de Aguiar, Madeleine Leininger and Hildegard Peplau were outlined. Each student was responsible for deepening the concepts about the phenomena and attributes of each theory. The contents were presented by the students through seminars according to the schedule.

Conceptual maps and diagrams containing the main concepts and their attributes were constructed to identify the points of contact between the nursing theories studied and the nurse's praxis.

The contextualization of the concepts and of their characteristics were analyzed, an attempt to approach the phenomena to the nursing professional's reality occurred and the relationship they establish with the autonomy of nurses.

Knowledge was developed by approaching the concepts of the theories to the professional reality of each student, which represents significant learning. The learning in the discipline was evaluated through students'feedback regarding the two themes presented in this report.

\section{LESSONS LEARNED}

The lessons learned emerging from the philosophical basis and the two topics are described as construction of learning in the discipline.

\section{REFLEXIVE ASSUMPTIONS}

Philosophy predicts concepts that structure the processes of reasoning, establishing knowledge and revealing fundamentals(1). Nursing, as a science, is established from a substantial knowledge that represents its nature. The philosophy of science, in the field, determines the meaning of science through the understanding of concepts, theories, laws and performance goals as they relate to the practice. As science, nursing has phenomena that can be described, identifies causalities and relates these processes critically to theories, models and scientific systems ${ }^{(1)}$.

The historical construction of the scientific thought process in nursing occurred thanks to Florence Nightingale, who, in her career, identified knowledge and contents for the decisionmaking process in the field. She delimited moral standards for the professional profile and related them with the diseases and the environment in the health maintenance. The focus of the period, called "modern nursing"(2), permeated the "what to do"?

Between 1920 and 1930, knowledge was developed focused on "how to do", and the method used was the case study, which promoted the systematization of thought. In this period, the advance of the sciences physics and chemistry allowed technological progress in Medicine aiming at treating diseases. The number of hospitals increased and the combination of nursing and health practices in the same space occurred, which influenced the biomedical care model in nursing practice ${ }^{(3)}$.

Between 1950 and 1960, discussions aimed to conceptualize nursing as a science emerged. In this context, the nursing theories formulated by some North American women delimited the role of the nurse in relation to other professionals ${ }^{(4)}$. 
Nursing theory is defined as an organized, coherent and systematic articulation of concepts related to the discipline. It aims to describe the phenomena, explain the relationship between them and predict consequences or prescribe the nursing care. It is done to meet the interests of the scientific community and society ${ }^{(5)}$.

In this way, nursing theories contribute to the planning of nursing care through the conceptual framework constructed based on the care phenomena. This practice is consolidated by the nursing process.

The nursing process was introduced in the United States in 1970, with the following phases: assessment, diagnosis, planning, implementation, and evaluation. In parallel, the standardization of terms of nursing diagnoses was introduced by the North American Nursing Diagnosis Association ${ }^{(4)}$. In the 1980s, in the same country, the creation of taxonomies of interventions and outcomes in nursing contributed to the identity, visibility and autonomy of the nursing practice development ${ }^{(4)}$.

In Brazil, the National Federal Council of Nursing (COFEN) decided that nursing care systematization (SAE) is restricted to the nurse and must be implemented where the nursing care is performed, using the scientific method and having the theories of the field as basis ${ }^{(6)}$.

Currently, nurses seek to recognize their own knowledge, due to the perception that the scientific principles come from and depend on other sciences. The body of knowledge of nursing should be developed based on specific theories produced for the field, giving it status of science ${ }^{(2)}$.

Nursing theories allow reflection and the development of the nurse's critical and clinical thinking aiming at the human being and its biological, psychological, spiritual and social needs ${ }^{(2)}$. The theoretical framework institutionalizes and favors the training of nurses and the structuring of their scientific reasoning. The concepts of humanity/individuality, society/environment, health and nursing are important references for the nursing care models and their philosophical conceptions $\mathbf{s}^{(1,7)}$.

Due to the need for recognizing the meaning of the nursing world, the theories propose to identify, describe and explain the phenomena of nursing, solidifying the concepts on which the profession is based.

Thus, the intention is to reflect on two main issues: the training of the undergraduate student in Nursing and development of his/her knowledge in relation to concepts from nursing theories and care models; and the critical thinking of the nurse on the applicability of nursing theories.

\section{THE TRAINING OF THE UNDERGRADUATE STUDENT IN NURSING AND THE DEVELOPMENT OF KNOWLEDGE IN RELATION TO CONCEPTS FROM NURSING THEORIES}

Nursing theories play a key role because they support the nursing practice with their conceptual, epistemological and care descriptive bases, leading the "thinking" of the student when identifying nursing problems during the experience of care. Considering the training of the student and the direction of his/her reasoning is necessary to understand and identify the phenomena of care in the professional practice.

Over time, the "knowing" and the "being" of nursing were formed based on religious models of care that lasted until the late 19th century. These models were based on homemade procedures carried out by volunteer groups from churches and even by slaves. The care was aimed at the most needy.

The "modern nursing", arising from the model of vocational and disciplinary approach developed by Florence Nightingale, derived from her experiences in the Crimean War - contributed to the scientific enlightenment about the nurse's training. With the industrial development, in the middle of 1940 until 1960, nursing was based on the scientific knowledge that was being structured with the development of the nursing theories ${ }^{(2)}$. This historical note elucidates the evolution of the knowledge production in the field and demonstrates the conceptual ideas in the professional training.

Nursing theories provide an opportunity for reflection so that the undergraduate students can associate their actual work activities with the concepts formulated in the field. This allows assigning meaning to the actions and to the evaluation of the practice. Understanding the potential of the theoretical support provided by the theories offers opportunities for the students to resign the didactic scenario and to use its transformation power in their care actions.

However, results of this training in the nurses' practice are not observed, because there is a gap in the curricular and educational structuring of these professionals. Perceptions of undergraduate students regarding the praxis are distant from the way nursing theories are applicable and can contribute to develop their knowledge.

One believes that the contents regarding the concepts of the theories should permeate transversally the curricular structures of nursing schools so that they can subsidize the future professional practice of the students. The appropriation and internalization of a body of knowledge on nursing theories provide a reflective practice based on ethical, epistemological and ontological principles.

\section{CARE MODELS AND NURSES' CRITICAL REASONING ON THE APPLICABILITY OF NURSING THEORIES}

The reflections made in the context of this theme were based on theoretical assumptions common to all the theorists and their respective conceptual characteristics.

The use of the theoretical model of nursing must represent and meet the demand from this scenario. The form of organization of the database will distinguish the models, encompassing different approaches for care, because the different nursing models lead to various ways of care, which may be more humanized and qualified ${ }^{(3)}$.

Due to the fact that nursing is inserted in contexts characterized by a hospital-centered, fragmented and technical biomedical care, the profiles of work of nurses with different conceptual models of the profession that structure their clinical reasoning can be influenced.

The healthcare practice of nursing and the increase in professional autonomy depend on the incorporation of knowledge of the profession. This "knowing" is related to the "being", sustained by the theories of the field ${ }^{(8)}$.

Disconnection is identified between the formal curriculum and the nurses' praxis, with a tendency by the professionals to adhere to routine practices instead of applying reflective practices ${ }^{(9)}$.

This discrepancy may be related to some factors that were objects of reflection during the activities of the discipline. Among them, reduction in contents on nursing theories during 
undergraduate course; lack of attribution of meanings and senses of theoretical concepts for the professional practice; and curricular contents focused on the biomedical model.

The nurse's praxis must involve his/her knowledge regarding the transformations and innovations adapted to new care trends, seeking the promotion of health and well-being of the human being ${ }^{(10)}$. Necessarily, due to social, political and economic changes, the body of knowledge of nursing should be enhanced to follow and propose an advanced care.

Then, the construction of the base of the scientific knowledge of nursing originated in the creation of nursing theories and, currently, requires the incorporation of new knowledge for developing technologies in education, research, assistance and management ${ }^{(10)}$.

The experience, having this discipline as method and content, provided moments of reflection between teacher and students, resulting in the elaboration of the themes comprising the lessons learned. The reflections from the discussions in the classes were indispensable for developing and understanding the knowledge and representative meanings of the nurse's care practice, based on the assumptions and constructs of the nursing theories addressed.

The implementation of efforts and the knowledge acquisition by the nurse regarding how theoretical concepts of the field can cooperate and guide the individualized and humanized care were considered indispensable.

One believes that using definitions of terms contemplated by the nursing theories, as man, society, health, nursing and nurse, since the first year of the nursing undergraduate course would favor the use of theoretical constructs in praxis.

\section{Study limitations}

Due to the limitation of the time proposed for a elective discipline, theories by Dorothea Orem, Ida Jean Orlando, Wanda de
Aguiar Horta, Madeleine Leininger and Hildegard Peplau were used in the contexts of teaching, research and care. The exclusive use of those theories limited the approach to other theories.

A case report has limitations concerning its reproduction due to the fact that the actors involved and the topic proposed are specific conditions and may show different results when applied by others.

\section{Contributions to the nursing field}

The reflections triggered and themes that emerged during the discussions in the classes showed points of contact between the theoretical nursing concepts studied and the nurse's practice. These points are: the deliberate actions are similar to the interventions and activities of nursing recommended as standard terminology; nursing care needs are denominated by nursing diagnoses as well as by the self-care deficits; the concepts "therapeutic relationship" and "humanized and individualized care" are close, which confirms the completeness of the care.

\section{FINAL CONSIDERATIONS}

In the training of the undergraduate student in nursing, the understanding of the function and social role of the nurse is essential for the full, legal, ethical and moral exercise of the profession. The nurses that recognize the conceptual meanings of the nursing theories since their training helps in giving meaning to the healthcare practice and can stand out in the construction of the reasoning and clinical judgment, as well as in the choice of the best nursing interventions and identification of phenomena for which these professionals are responsible. Therefore, they can achieve the best results. The obligation of integrating contents related to this topic into the undergraduate nursing curricula is recommended.

\section{REFERENCES}

1. McEwen M, Bases teóricas de enfermagem. 4ª ed. Porto Alegre: Artmed; 2016.

2. Backes DS, Backes MTS, Erdmann AL, Büscher A. [From nursing nightingalean pattern to Luhmann's social system: theoretical study]. Rev Bras Enferm [Internet]. 2013[cited 2018 Jun 1];66(4):599-602. Available from: http://dx.doi.org/10.1590/S0034-71672013000400020 Portuguese

3. Petersen CB, Lima RAG, Boemer MR, Rocha SMM. Health needs and nursing care. Rev Bras Enferm [Internet]. 2016 [cited 2018 May 21];69(6):1236-9. Available from: http://dx.doi.org/10.1590/0034-7167-2016-0128

4. Almeida MCP, Mishima SM, Pereira MJB, Palha PF, Villa TCS, Fortuna CM, et al. Nursing as a discipline: what scientific knowledge field identifies the profession? Rev Bras Enferm [Internet]. 2009[cited 2018 May 21];62(5):748-52. Available from: http://dx.doi.org/10.1590/ S0034-71672009000500017

5. Ramalho Neto JM, Marques DKA, Fernandes MGM, Nóbrega MML. Meleis' Nursing Theories Evaluation: integrative review. Rev Bras Enferm [Internet]. 2016 [cited 2018 May 21];69(1):174-81. Available from: http://dx.doi.org/10.1590/0034-7167.2016690123i

6. Conselho Federal de Enfermagem. Resolução n 358, de 15 de outubro de 2009, dispõe sobre a Sistematização da Assistência de Enfermagem e a implementação do Processo de Enfermagem em ambientes, públicos ou privados, em que ocorre o cuidado profissional de Enfermagem, e dá outras providências. Diário Oficial da União, 15 out 2009; Seção 1:188.

7. Pinto AC, Garanhani ML, Franca TE, Pierotti I. The concept of the human being in nursing theories: establishing a relationship with the teaching of the human condition. Pro-Posições [Internet]. 2017 [cited 2018 May 28];28(1):88-110. Available from: http://dx.doi. org/10.1590/1980-6248-2015-0164

8. Melo CMM, Florentino TC, Mascarenhas NB, Macedo KS, Silva MC, Mascarenhas SN. Professional autonomy of the nurse: some reflections. 
Esc Anna Nery [Internet]. 2016 [cited 2018 June 1];20(4):e20160085. Available from: http://dx.doi.org/10.5935/1414-8145.20160085

9. Morán L, Quezada Y, García A, González P, Godínez S, Aguilera M. [Problem-solving and decision-making, essence of reflexive practice in nursing: a literature review]. Enferm Univ [Internet]. 2016 Mar [citado 2018 Jun 1];13(1):47-54. Available from: http://www.scielo.org.mx/pdf/ eu/v13n1/1665-7063-eu-13-01-00047.pdf Spanish.

10. Álvarez YDM. [Nursing in Latin America: a look at the horizon]. Av Enferm [Internet]. 2015 May [cited 2018 June 1];33(2):295-305. Available from: http://www.scielo.org.co/pdf/aven/v33n2/v33n2a11.pdf Spanish. 